\title{
PARTISIPASI POLITIK PEMILIH PEMULA PADA PEMILIHAN KEPALA DAERAH KABUPATEN BOMBANA TAHUN 2017 DI KELURAHAN TAUBONTO
}

\author{
Uchi Indah Sari, Karsadi, Muh. Idrus \\ Jurusan Pendidikan Pancasila dan Kewarganegaraan \\ Fakultas Keguruan dan Ilmu Pendidikan \\ Universitas Halu Oleo \\ Email: uchiindahsari@gmail.com,karsadi2017@gmail.com, muhammad.idrus@uho.ac.id
}

\begin{abstract}
Abstrak: Tujuan penelitian ini adalah (1) untuk mengetahui bentuk partisipasi politik pemilih pemula pada Pemilihan Kepala Daerah Kabupaten Bombana Tahun 2017 di Kelurahan Taubonto (2) untuk mengetahui faktor penghambat Partisipasi Politik Pemilih Pemula pada Pemilihan Kepala Daerah Kabupaten Bombana Tahun 2017 di Kelurahan Taubonto. Penelitian ini dilakukan di Kelurahan Taubonto, Kecamatan Rarowatu, Kabupaten Bombana dengan menggunakan analisis kualitatif. Informan penelitian adalah Lurah Taubonto, Tokoh Masyarakat, dan Tokoh Agama dan responden adalah pemilih pemula sebanyak 18 orang yang terdaftar pada pemilihan Kepala Daerah Kabupaten Bombana Tahun 2017. Teknik pengumpulan data penelitian ini adalah wawancara dan dokumentasi. Hasil penelitian menunjukkan bahwa bentuk partisipasi yang dilakukan pemilih pemula adalah (1) Pemberian suara (voting), pemilih pemula antusias menggunakan hak pilihnya karena ini merupakan pemilihan pertama mereka (2) diskusi politik, pemilih pemula secara berkelompok terlibat dalam diskusi kecil untuk menentukan siapa calon kandidat pilihan mereka (3) kegiatan kampanye, memberikan dukungan pada kadidat calon kepala daerah menjadikan pemilih berpartisipasi dalam kampanye, dan (4) Membentuk dan bergabung dalam kelompok kepentingan, pemilih pemula di Kelurahan Taubonto belum ada yang tergabung dalam kelompok kepentingan contohnya bergabung dalam kepengurusan partai politik. Ada beberapa faktor penghambat parisipasi politik pemilih pemula di Kelurahan Taubonto seperti kesibukan kegiatan sehari-hari pemilih pemula yang harus bersekolah, perasaan tidak mampu, adanya larangan dari pihak keluarga untuk mengikuti kegiatan kampanye karena jarak tempuh yang jauh. Simpulan penelitian ini adalah partisipasi politik pemilih pemula di Kelurahan Taubonto relatif rendah hal ini dilihat dari rendahnya keikutsertaan mereka dalam berbagai kegiatan politik. Kesibukan sehari-hari, larangan dari pihak keluarga dan perasaan tidak mampu menjadi faktor penghambat partisipasi pemilih.
\end{abstract}

\section{Kata Kunci: Partisipasi Politik dan Pemilih Pemula}

\section{PENDAHULUAN}

Partisipasi politik dalam negara demokrasi merupakan indikator implementasi penyelenggaraan kekuasaaan negara tertinggi yang absah oleh rakyat (kedaulatan rakyat), yang dimanifestasikan keterlibatan mereka dalam pesta demokrasi (Pemilu). Makin tinggi tingkat partisipasi politik mengindikasikan bahwa rakyat mengikuti dan memahami serta melibatkan diri dalam kegiatan kenegaraan. Sebaliknya tingkat partisipasi politik yang rendah pada umumnya mengindikasikan bahwa rakyat kurang menaruh apresiasi atau minat terhadap masalah atau kegiatan kenegaraan. Rendahnya tingkat partisipasi politik rakyat direfleksikan dalam sikap golongan putih (golput) dalam pemilu. 
Menurut pasal 1 ayat (22) UU No 10 Tahun 2008 Tentang Pemilihan Umum Anggota Dewan Perwakilan Rakyat, Dewan Perwakilan Daerah, dan Dewan Perwakilan Rakyat Daerah, pemilih adalah warga Negara Indonesia yang telah genap berumur 17 (tujuh belas) tahun atau lebih atau sudah/pernah kawin, kemudian pasal 19 ayat (1 dan 2) UU No 10 Tahun 2008 menerangkan bahwa pemilih yang mempunyai hak memilih adalah warga Negara Indonesia yang di daftar oleh penyelenggara Pemilu dalam daftar pemilih dan pada hari pemungutan suara telah genap berumur 17 (tujuh belas) tahun atau lebih atau sudah/pernah kawin.

Menurut konsep demokrasi bahwa pemilih pemula juga mendapat peluang dalam kehidupan politik, karena dari sinilah politik yang dapat mengatur negara dapat dibangun. Bagaimanapun, pemilih pemula dapat menjalankan program ini hanya jika dirinya mempunyai kesadaran untuk hidup demokratis. Remaja tidak akan dapat menciptakan suasana demokratis dalam kehidupan politik jika remaja tersebut itu sendiri tidak bersifat demokratis. Secara logikanya, bahwa dalam suatu sistem politik yang demokratis dibutuhkan masyarakat (remaja) yang demokratis juga. (Surbakti, 1999:12).

Salah satu aktivitas politik yang dilakukan oleh pemilih pemula adalah dengan memberikan suara dalam Pemilihan Umum (Pemilu). Pemilu merupakan bukti bahwa suatu negara menjamin hak warganya untuk memilih secara bebas. Saat pemilihan kepala daerah diharapkan pemilih pemula sebagai generasi harapan bangsa memiliki tingkat partisi politik yang tinggi dan ikut dalam seluruh kegiatan pemilihan tersebut mulai dari pencalonan sampai pada penetapan kepala daerah terpilih dalam rapat pleno KPU dan ikut dalam pengambilan keputusan.

Pemilih pemula sekarang ini masih banyak tidak menggunakan hak pilihnya dalam pemilihan umum kerena sebagian pemilih pemula tidak peduli dengan dilaksanakannya pemilihan umum tersebut, selain itu sebagian pemilih pemula menggunakan hak pilih mereka dengan baik seperti halnya memilih karena sesuatu alasan tertentu bukan karena memilih untuk mendapatkan pemimpin yang betul-betul bisa memimpin Negara ini dengan baik. Oleh karena itu perlu adanya pemahaman- pemahaman yang baik agar Pemilu berikutnya pemilih pemula dapat menggunakan hak pilihnya dengan baik.

\section{Konsep Partisipasi Politik}

Budiardjo (Sahid, 2011: 178). Ia memandang partisipasi politik sebagai kegiatan seseorang atau kelompok orang untuk ikut secara aktif dalam kehidupan politik, misalnya dalam pemilihan pemimpin Negara, mempengaruhi kebijaksanaan Negara dan berbagai kegiatan lainnya. Menurut Mc Closky, seorang tokoh masalah partisipasi (Bodiardjo, 2014: 367) bahwa, Partisipasi politik adalah kegiatan-kegiatan sukarela dari warga masyarakat melalui mana mereka mengambil bagian dalam proses pemilihan penguasa, dan secara langsung atau tidak langsung, dalam proses pembentukan kebijakan umum. Hal yang diteropong terutama adalah tindakan-tindakan yang bertujuan untuk mempengaruhi keputusan-keputusan pemerintah, sekalipun fokus utamanya lebih luas tetapi abstrak, yaitu usaha-usaha untuk mempengaruhi alokasi nilai secara otoratif untuk masyarakat. 


\section{Bentuk-Bentuk Partisipasi Politik}

Bentuk partisipasi politik seseorang tampak dalam aktivitasaktivitas politiknya. Bentuk partisipasi politik yang paling umum dikenal adalah pemungutan suara (voting) entah untuk memilih calon wakil rakyat atau untuk memilih kepala negara (Maran, 2001:148). Menurut Sahid (2011, 178), partisipasi politik dapat dilihat dari berbagai sudut pandang. Bentuk umum dari partisipasi politik adalah pemberian pada saat pemilihan umum (pemilu). Bentuk partisipasi politik paling minim seperti ini dapat dijumpai pada sistem politik demokrasi sampai paling otoritarium sekalipun.

\section{Konsep Pemilih Pemula}

Peraturan Komisi Pemilihan Umum Republik Indonesia Nomor 8 Tahun 2017 Tentang Sosialisasi, Pendidikan Pemilih dan Partisipasi Masyarakat dalam Pemilihan Gubernur dan Wakil Gubernur, Bupati dan Wakil Bupati, dan/atau Walikota dan Wakil Walikota Pasal 1 ayat 8 "pemilih adalah penduduk yang berusia paling rendah

17 (tujuh belas) tahun atau sudah/pernah kawin yang terdaftar dalam Pemilihan”.

\section{Bentuk-Bentuk Partisipasi Politik Pemilih Pemula}

Menurut Saputra (2017: 8), bentuk-bentuk partisipasi politik yang dilakukan oleh pemilih pemula berupa:

a. Pemberian suara (voting)

Pemberian suara (voting) adalah suatu kegiatan untuk menentukan pendapat melalui suara terbanyak berfungsi menyelesaikanpermasalahan melalui pemungutan suara dan suara terbanyak adalah pemenang. Tingginya persentase pemilih pemula yang memberikan suaranya dalam pemilihan, menunjukkan bahwa pemilih pemula tidak kalah antusias seperti halnya masyarakat yang lain b. Diskusi politik

Lingkungan tempat tinggal, lingkungan pekerjaan, maupun tingkat pendidikan dapat mempengaruhi minat politik seorang pemilih pemula. Pemilih pemula yang tinggal di lingkungan dengan kesadaran politik yang tinggi, dimana pemilih pemula dengan kelompok masyarakat yang lain tidak ada batasan, maka ia tidak akan segan membicarakan segala sesuatu tentang dunia politik, bahkan ikut terjun didalamnya. Demikian juga dengan pemilih pemula yang bekerja pada lingkungan yang mendukung dunia politik, maka ia pun tidak segan untuk bicara tentang politik. Berikutnya pemilih pemula yang mempunyai tingkat pendidikan tinggi seperti mahasiswa. Dunia kemahasiswaan adalah tempat yang tidak dapat dipisahkan dari dunia politik. Mahasiswa selalu idealis dan selalu menganalisis tiap kejadian politik di dalam negara.

Di musim pemilihan umum, orang suka membicarakan tentang masalah-masalah dan peristiwa-peristiwa politik yang terkait. Meskipun bersifat informal, tidak jarang diskusi-diskusi semacam itu berlangsung menarik. Mungkin disitu orang bebas mengluarkan pendapat serta sikappolitiknya. Hal ini dimungkinkan karena adanya hubungan persahabatan serta kekeluargaan di antara peserta diskusi tersebut. Pemilih pemula sering membicarakan bahkan mendiskusikan tentang masalah pemilu dengan teman-teman dalam satu kerjaan maupun teman sekolah di sela-sela kegiatan mereka sehari-hari. Karena membicarakan masalah politik merupakan bentuk partisipasi politik yang mudah untuk dilakukan oleh semua orang. Namun demikian, tidak semua orang dapat 
melakukannya dalam kenyataannya memang hanya pemilih pemula tertentu saja yang suka membicarakan masalah politik.

c. Kegiatan kampanye

Bentuk partisipasi politik paling banyak dilakukan pemilih pemula adalah kampanye. Mereka ikut kampanye dengan berbagai alasan antara lain ada yang benar-benar ingin mendengarkan visi dan misi juru kampanye partai politik yang berorasi maupun hanya sekedar ikut-ikutan karena ingin menikmati keramaian atau mendapatkan hiburan.

d. Membentuk dan bergabung dalam kelompok kepentingan

Kesadaran politik warga negara menjadi faktor determinan dalam partisipasi politik masyarakat, artinya sebagai hal yang berhubungan dengan pengetahuan dan kesadaran akan hak dan kewajiban yang berkaitan dengan lingkungan masyarakat dan kegiatan politik menjadi ukuran dan kadar seseorang terlibat dalam proses partisipasi politik. Begitu juga dengan pemilih pemula yang baru mamasuki usia hak pilih sebagian besar belum memiliki jangkauan politik yang luas untuk menentukan ke mana mereka harus memilih.

\section{Pemilihan Langsung Kepalan Daerah}

Berdasarkan UUD NRI Tahun 1945 tentang Pemilihan Kepala Daerah Pasal 18 ayat (4) UUD NRI Tahun 1954 dinyatakan bahwa "Gubernur, Bupati dan Walikota masing-masing sebagai kepala pemerintah daerah provinsi, kabupaten, dan kota dipilih secara demokratis".

\section{Faktor Penghambat Partisipasi Politik Pemilih Pemula}

Menurut Saputra (2017), bahwa: faktor-faktor penghambat partisipasi politik pemilih pemula antara lain:

1. Kesibukan kegiatan sehari-hari

Peranan pemilih pemula yang sangat komplek dalam kegiatan sehari- hari untuk memenuhi tanggung jawab mereka terhadap pribadinya, selalu menjadi faktor utama yang menghambat keterlibatan mereka dalam kegiatan pemilihan umum. Mereka lebih memilih untuk melaksanakan kegiatan mereka daripada harus ikut serta dalam urusan pemilu. Para pemilih pemula umurnya berkisar 17-21 tahun umumnya merupakan pelajar, mahasiswa, dan pekerja muda. Hal inilah yang menjadikan para pemilih pemula enggan melakukan kegiatan politik yang umumnya menyita waktu yang banyak. Tuntutan sebagai pelajar dan bekerja menjadi alasan utama bagi para pemilih pemula enggan melakukan kegiatannya di bidang politik.

2. Perasaan tidak mampu

Mereka merasa tidak berhak tampil dalam kegiatan politik dari pada mereka yang punya setatus sosial ekonomi yang tinggi dan pengalaman yang memadai. Mereka menyadari bahwa kenyataan yang ada dalam masyarakat adalah politik lebih berhak bagi mereka yang punya pengalaman dan mempunyai setatus sosial ekonomi yang cukup. Dengan adanya gejala seperti ini mereka akan merasa lebih aman dan nyaman jika hanya berada di sektor privat.

3. Larangan dari pihak keluarga

Dalam hal ini, sebenarnya pihak keluarga dapat menjadi pengaruh atau perangsang utama bagi seseorang untuk berpartisipasi politik namun ternyata pihak keluarga justru melarang, maka partisipasi politik tidak akan terwujud. Mereka masih mementingkan keluarga di atas kepentingan yang lain. Jadi 
ketika anggota keluarga yang lain tidak setuju dengan suatu aktifivitas yang kita lakukan, maka lebih baik berhenti melakukannya. Demikian juga dengan aktivitas politik pemilih pemula dalam pemilu ketika anggota keluarga ada yang melarang, maka mereka akan segera mematuhinya.

\section{METODE PENELITIAN}

Penelitian ini menggunakan pendekatan deskriptif kualitatif. Responden dalam penelitian ini adalah beberapa pemilih pemula yang terdaftar dalam pemilihan kepala daerah Kabupaten Bombana tahun 2017 di Kelurahan Taubonto, Kecamatan Rarowatu, Kabupaten Bombana. Sedangkan informan dalam penelitian ini adalah petugas PPS Kelurahan Taubonto, Lurah Kelurahan Taubonto dan tokoh masyarakat lainnya. Teknik dalam pengumpulan data yang digunakan adalah wawancara dan dokumentasi. Teknik analisis data menggunakan data kualitatif yakni Data Reduction (Reduksi Data); Data Display (Penyajian Data); dan Conclution Drawing/Verivication (Penarikan Kesimpulan). Miles dan Huberman (Sugiyono, 2014)

\section{HASIL PENELITIAN DAN PEMBAHASAN}

\section{Partisipasi Politik Pemilih Pemula pada Pemilihan Kepala Daerah Kabupaten Bombana Tahun 2017 di Kelurahan Taubonto}

Bentuk partisipasi politik seorang tampak dalam aktivitas-aktivitas politiknya begitu pula dengan pemilih pemula yang ada di Kelurahan Taubonto, Kecamatan Rarowatu, Kabupaten Bombana. Berdasarkan Hasil penelitian yang dilakukan peneliti mengenai partisipasi politik pemilih pemula pada pemilihan kepala daerah Kabupaten Bombana tahun 2017 di Kelurahan Taubonto diperoleh melalui wawancara dengan responden dan informan pemilih pemula di Kelurahan Taubonto partisipasi politik yang mereka lakukan yaitu sebagai berikut:

1. Pemberian Suara (Voting)

Kegiatan politik pada tahap pemilihan kepala daerah hanya diikuti sebagian pemilih pemula saja, hal ini dikarenakan partisipasi pemilih pemula pada pemilihan kepala daerah Kabupaten Bombana relatif rendah, hal ini dibuktikan pada hari pemilihan di dua TPS di Kelurahan Taubonto sebagian pemilih memilih untuk pergi ke TPS tetapi sebagiannya lagi memilih untuk tidak pergi memilih atau golput dengan alasan melakukan kegiatan sehari-hari mereka yaitu bekerja di sawah, berkebun atau memeriksa ternak mereka. Namun ada juga yang tidak berpartisipasi pada hari pemilihan karena merasa malas dan beranggapan kalau hal tersebut tidak membawa berdampak untuk kehidupanya.

2. Diskusi Politik

Di Kelurahan Taubonto pemilih pemula tidak secara resmi membentuk kelompok-kelompok, mereka melakukan diskusi ketika secara kebetulan bertemu disuatu tempat kemudian saling mengajukan pertanyaan perihal siapakah calon kandidat yang akan mereka pilih.

3. Kegiatan Kampanye

Pada tahap kampanye pemilih pemula di Kelurahan Taubonto aktif berpartisiapasi dalam kegiatan kampanye, hal ini karena adanya ajakan dari orang 
tua, selain itu adanya hubungan keluarga rasa ingin tahu mereka terkait visi misi kandidat calon kepala daerah, latar belakang pendidikan, dan prestasi menjadi salah satu alasan pemilih begitu antusias untuk berpartisipasi dalam kegiatan kampanye, selain itu adanya hubungan keluarga menjadikan pemilih berpartisipasi dalam kampanye

4. Membentuk dan Bergabung dalam Kelompok Kepentingan

Pemilih pemula di kelurahan taubonto tidak pernah mendapat ajakan dari kader partai untuk bergabung dalam struktur keanggotaan partai politik. Selain itu pemilih pemula juga tidak berminat untuk bergabung dalam kepengurusan partai politik disebabkan banyak faktor diantaranya tidak berminat bergabung dalam partai politik dan memiliki kesibukan sehari-hari sehingga pemilih sulit membagi waktu antara bekerja dengan mengurus kegiatan partai

\section{Faktor Penghambat Partisipasi Politik Pemilih Pemula pada Pemilihan Kepala Daerah Kabupaten Bombana di Kelurahan Taubonto}

Partisipasi politik sebagai aktifitas pemilih pemula tentu mengalami berbagai hambatan, pada pemilihan Kepala Daerah Kabupaten Bombana Tahun 2017, terdapat beberapa faktor yang menjadi penghambatan pemilih dalam partisipasinya, faktor- faktor tersebut antara lain sebagai berikut:

1. Kesibukan Kegiatan Sehari-hari

Peranan pemilih pemula yang begitu banyak, seperti harus bersekolah, bekerja dan juga mengerjakan berbagai macam pekerjaan rumah tangga menjadi penghambat mereka tidak dapat mengikuti berbagai kegiatan politik. Hal ini yang menjadi faktor penghambat keterlibatan mereka dalam kegiatan politik.

2. Perasaan Tidak Mampu

Pemilih pemula di Kelurahan Taubonto seringkali beranggapan bahwa hanya pemilih yang berpengalaman saja yang lebih berhak mengikuti semua kegiatan politik yang ada, mereka cenderung tidak melakukan kegiatan politik karena merasa masih muda dan masih ada yang lebih berpengalaman yang lebih berhak berpartisipasi dalam kegiatan politik.

3. Larangan dari Pihak Keluarga

Salah satu yang menjadi hambatan partisipasi politik pemilih pemula di Kelurahan Taubonto yaitu adanya larangan dari orang tua. Naluri orang tua utamanya ibu yang selalu mengkhawatirkan anaknya ketika berada jauh dari jangkauan mereka menjadikan orang tua cenderung melarang anak mereka untuk bepergian ketempat yang jauh dari rumah. Hal ini juga terjadi saat anak atau pemilih pemula hendak berpartisipasi dalam kegiatan politik lalu orang tuanya selalu melarang untuk terlibat, misalnya saja untuk mengikuti kegiatan kampanye atau pendaftaran calon ke KPU, beberapa pemilih yang berada di Kelurahan Taubonto dilarang terlibat karena untuk ikut kampanye harus menempuh jarak $17 \mathrm{KM}$ dari rumah mereka.

\section{KESIMPULAN DAN SARAN \\ Kesimpulan}

1. Bentuk-bentuk partisipasi politik pemilih pemula pada Pemilihan Kepala Daerah Kabupaten Bombana Tahun 2017 di Kelurahan Taubonto terdiri dari pemberian suara (voting), diskusi politik, kegiatan kampanye, berdasarkan 
penelitian dilapangan diperoleh data bahwa bentuk partisipasi yang paling dominan diikuti oleh pemilih pemula adalah pemberian suara (voting).

2. Faktor-faktor yang menghambat partisipasi politik pemilih pemula pada pemilihan Kepala Daerah Kabupaten Bombana Tahun 2017 di Kelurahan Taubonto yakni, kesibukan kegiatan sehari-hari, perasaan tidak mampu dan larangan dari pihak keluarga.

\section{Saran}

1. Pemerintah harus lebih sering lagi melakukan sosialisasi dan edukasi utamanya kepada pemilih pemula yang putus sekolah dan pemilih pemula yang merupakan pekerja muda tentang partisipasi politik, manfaat partisipasi mereka, serta tata cara untuk berpartisipasi dalam kegiatan politik.

2. Pemerintah sebaiknya memberikan pemahaman kepada orang tua agar tidak menghalangi atau membatasi anaknya dalam hal ini pemilih pemula untuk mengikuti kegiatan politik.

\section{DAFTAR PUSTAKA}

Boediardjo, Miriam. 2014. Dasar-dasar Ilmu Politik. Edisi Revisi, Cetakan Kesepuluh. Jakarta: Gramedia Pustaka Utama.

Komisi Pemilihan Umum. 2017. Peraturan Komisi Pemilihan Umum Republik Indonesia Nomor 8 Tahun 2017 Tentang Sosialisasi, Pendidikan Pemilih dan Partisipasi Masyarakat dalam Pemilihan Gubernur dan Wakil Gubernur, Bupati dan Wakil Bupati, dan/atau Wali kota dan Wakil Wali kota. Jakarta.

Maran, Rafael Raga. 2001. Pengantar Sosiologi Politik. Jakarta: PT. Rieneka Cipta Sahid, Komarudin. 2011. Memahami Sosiologi Politik. Bogor: Ghalia Indonesia.

Saputera, Rezeky. 2017. "Partisipasi Politik Pemilih Pemula pada Pemilihan Presiden di Kecamatan Mandau Kabupaten Bengkalis Tahun 2014". JOM FISIP Vol. 4 No. 1. https://jom.unri.ac.id/index.php/JOMFSIP/issue/view/398/ showToc, tanggal 27 November 2018.

Sugiyono, 2014. Memahami Penelitian Kualitatif. Bandung: ALFABETA

Surbakti, Ramlan. 1999. Memahami Ilmu Politik. Jakarta: Gramedia Pustaka Utama

Undang-Undang No. 10 Tahun 2008 Tentang Pemilihan Umum Anggota Dewan Perwakilan Rakyat, Dewan Perwakilan Daerah, dan Dewan Perwakilan Rakyat Daerah.

UUD NRI Tahun 1945 tentang Pemilihan Kepala Daerah 